\title{
Reforming Prisoners and Prisons: Iowa's State Prisons- The First Hundred Years
}

\author{
JOYCE MCKAY
}

ON JANUARY 25, 1839, just two years after the town of Fort Madison was platted, Iowa's territorial legislature selected the fledgling community as the site for its territorial penitentiary. Recognizing that such an institution would offer a source of employment and create a market for goods and services, the president of the Territorial Council and the Speaker of the House- both from Fort Madison-succeeded in convincing the other legislators that Fort Madison's offer to donate property to the state for the penitentiary topped offers from Davenport, Bloomington, Dubuque, and Burlington.'

Unfortunately, the Fort Madison site made expansion there impractical. Thus, when the State Penitentiary suffered crowded conditions in the 1860 s, Iowa communities, including McGregor, Charles City, and Marshalltown, again competed to secure the proposed new prison. Armed with petitions from neighboring communities and a promise of donated farmland in addition to

The editor of the Annals of Iowa adapted this article, with the author's approval, from "Municipal, County, and State Corrections Properties in Iowa," National Register of Historic Places Multiple Property Documentation Form, 1992, Community Programs Bureau, State Historical Society of Iowa, Des Moines. Unless otherwise noted, the official state reports cited herein can be found printed and bound in the series of Legislative Documents compiled for the various General Assemblies from 1854 through 1931.

1. Laws of the Territory of Iowa, 1839, 365; Journal of the Council of the Legislative Assembly of the Territory of Iowa, 1839, 179-84, 196.

THE ANNALS OF IOWA 60 (Spring 2001). (C) The State Historical Society of Iowa, 2001. 
a site appropriate for the prison adjacent to a stone quarry, Senator John McKean succeeded in winning the institutioncalled simply the Additional Penitentiary and later the Men's Reformatory - for his hometown of Anamosa in $1872 .^{2}$

Prison overcrowding, combined with reformers' desire to separate different classes of prisoners, had led to the call for an additional penitentiary. Those contrasting considerations, along with the limitations of the existing site in Fort Madison, reflect an ongoing theme in the history of Iowa's state penitentiaries. Throughout their history, both institutions underwent significant but gradual changes in philosophy, policy, and practice, especially in the approach to prison discipline, the use of prison labor, and the spaces prisoners occupied as the state rebuilt or constructed its prisons. These changes reflected the nationwide shifts from an emphasis on penitence and reform through work rehabilitation to the progressive philosophies aimed at reshaping the prisoners' psychological and social outlook. However, political and economic considerations as well as conservatism limited the implementation of new reform programs. Reform practices generally followed by a generation or more the development of reform philosophy, and reform programs were often only partially instituted.

THE 1839 ACT to Provide for the Erection of a Penitentiary specified a penitentiary of sufficient size to receive, secure in separate cells, and employ at hard labor 136 inmates convicted of any "infamous" crime. The act further required that the superintendent overseeing construction model the facility "as nearly as convenient and may appear advisable" after the Connecticut State Prison at Wethersfield. ${ }^{3}$ Louis Dwight had designed that model prison, erected between 1825 and 1834, using the Auburn system. That system gained widespread acceptance in the $1830 \mathrm{~s}$ and 1840 s, a time when social reform movements flourished nationwide. The monumental prison architecture still evident to-

2. Laws of Iowa, 1872, 49-52; Wanita Zumbrunnen, "The White Palace of the West," Palimpsest 59 (1978), 88-90; Fred E. Haynes, The Iowa Prison System (Iowa City, 1956), 12.

3. Laws of the Territory of Iowa, 1839, 342. 


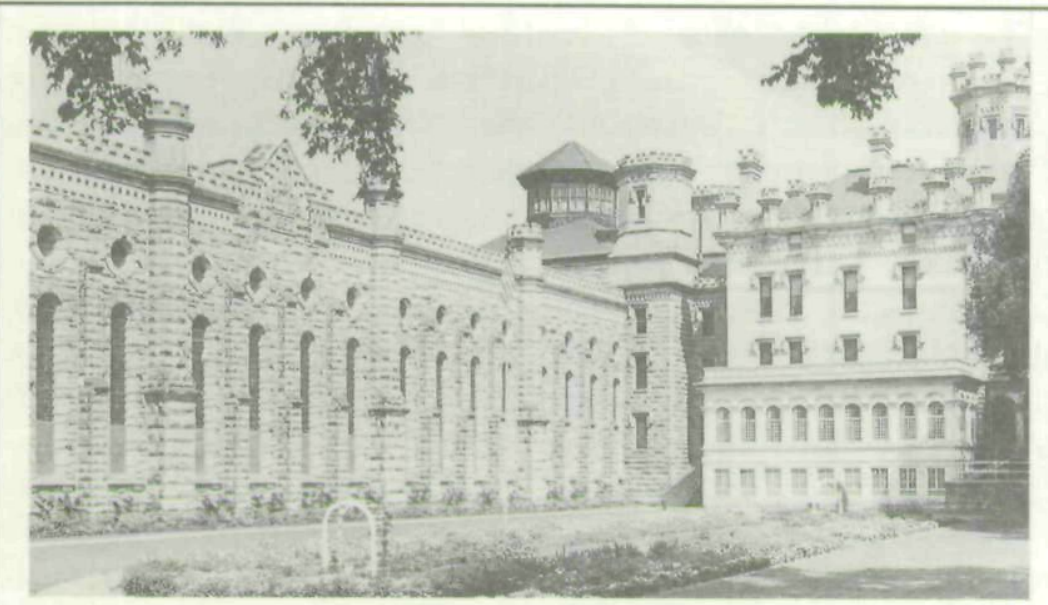

The monumental architecture produced by the Auburn prison system is evident in this view of the Men's Reformatory at Anamosa from the 1940s. Photo courtesy State Historical Society of Iowa, Iowa City (SHSI, IC).

day in many states, including Iowa, is a product of the Auburn system. ${ }^{4}$

Prior to the 1830s, legal codes in the United States had been administered primarily at the community level rather than by counties or states. Such communities, lacking the human and financial resources to retain offenders for long periods, held them in jails (or gaols) consisting of one or two large rooms with secure doors and substantial walls. Such jails were designed to detain individuals held for trial or indebtedness, not to administer punishment or correction. Punishments during this period, ranging from fines and removal from the community to flogging and execution, were not related to imprisonment and were designed as a deterrent to crime, not as a means to reform criminals. ${ }^{5}$

4. Blake McKelvey, American Prisons: A History of Good Intentions (Montclair, NJ, 1977), 15-16.

5. David J. Rothman, The Discovery of the Asylum: Social Order and Disorder in the New Republic (Boston, 1971), 42, 48-58, 89; Henry Burns, Origin and Development of Jails in America (Carbondale, IL, 1971), 8; S. Stephens, "Human Cage: A Brief History of Prison Architecture: A Review," Architectural Forum 138 (1973), 51; Norman Johnson, The Human Cage: A Brief History of Prison Architecture (New York, 1973), 6, 14. 
By the early nineteenth century, however, social reformers began to take a greater interest in the possibility of eradicating social problems and improving the human condition. They believed that social deviants could be reformed. At the same time, county and state governments increasingly took on roles previously neglected or performed only by local communities. While municipal and county governments retained responsibility for minor criminals, states assumed responsibility for more serious offenders. In that context, imprisonment, no longer merely detention prior to trial, became a punishment graded by the severity of the crime and intended to serve as a deterrent. ${ }^{6}$

From the 1830 s to the 1850 s, as states built penitentiaries to house criminals previously held in county jails, most chose to follow the Auburn system of discipline and architecture. The Auburn system sought to reform prisoners through regular habits, strict discipline, and hard work. Prisoners worked, exercised, and ate together during the day-all in complete silence -and retired to their individual cells at night. The Auburn system emphasized strict enforcement of an intricate system of rules with severe punishment for infractions. As the system evolved, securing order and obedience became more important than reform of the prisoner.

THAT WAS THE SYSTEM Iowa adopted in 1839. Construction began in Fort Madison that summer using the labor of available prisoners. Following the Auburn system, cells were placed back-to-back at the center of the cellblock, with ten-foot corridors along each side. A temporary, one-room cooper and blacksmith shop occupied one unfinished end of the cellhouse. The basement of the workshop served as the dining room and kitchen into the mid-1850s. To the detriment of security, a plank wall remained in place until 1857, when contractors began the stone prison wall that enlarged the yard sevenfold. Not sur-

6. James O. Finckenauer, Juvenile Delinquency and Corrections: The Gap between Theory and Practice (Orlando, FL, 1984), 113; McKelvey, American Prisons, 34, 4142, 60-61; Rothman, Discovery of the Asylum, 57-58, 67-79, 157; E. Ayers, "Just Measure: The Penitentiary in the Industrial Revolution, 1750-1850," Winterthur Portfolio 15 (1980), 82-85.

7. Rothman, Discovery of the Asylum, 79-88; McKelvey, American Prisons, 45, 48. 
prisingly, about one-third of the inmates housed at Fort Madison escaped until the mid-1840s. ${ }^{8}$

Construction continued sporadically and haphazardly. In 1859, the Board of Inspectors attempted to create an overall plan for future prison construction. As part of its preparation, a representative of the board investigated the construction and operation of the prison in Auburn, New York, as well as those modeled on it in Massachusetts and Ohio. The board then hired Gridley Bryant, an eastern architect, to prepare a general plan for Iowa's penitentiary. Unfortunately, the legislature rejected the board's resulting octagonal plan as too expensive. After 1860 , rather than adopting a master plan, the prison appears to have followed an evolving plan aimed at raising the walls of the cellhouse to accommodate four tiers of cells, 250 in all. It placed a female department in the warden's former dwelling outside the wall, built a new warden's dwelling, and erected a kitchen, dining hall, chapel, and hospital building in the prison yard. The cells were $3 \frac{1}{2} 2^{\prime} \times 5^{\prime} \times 7^{\prime}$ high with brick partitions and iron doors. The stone wall around the yard, begun in 1857, was finally completed in 1866. By 1877, there were twelve workshops made of brick. Although Iowa erected and enlarged its single cellhouse several times in the nineteenth century using the Auburn-type cellhouse, limited funding meant that it never achieved either the Wethersfield plan the territorial legislature originally stipulated or the octagonal arrangement of the Massachusetts State Prison proposed by the board in $1859 .^{9}$

8. Beulah White Walker, "History and Development of Fort Madison Penitentiary, 1839-1933" (M.A. thesis, State University of Iowa, 1934), 11-21; John E. Briggs, "A Penitentiary for Iowa," Palimpsest 20 (1939), 408; Official Register of Iowa, 1886, 75; Journal of the Iowa Territorial Council, 1840, 52-53, 209-10, 241-43; ibid., 1841, 272; ibid., 1842, 198-203; ibid., 1843, 19-20; ibid., 1845, 190; ibid., 1846, 51; Laws of the Territory of Iowa, 1841, 68; Iowa Territorial House Journal, 1846, 268.

9. Iowa Governor's Office, Series VII: Reports, Documents, State Institutions, Industrial Schools for Boys and Girls and State Penitentiaries, 10 July 1858, State Archives, State Historical Society of Iowa, Des Moines; Annual Report of the Board of Inspectors of the Iowa Penitentiary (hereafter cited as Board of Inspectors, Report), 1858; ibid., 1859, 9-12, 18, 29-31; Biennial Report of the Warden of the Iowa Penitentiary (hereafter cited as Warden's Report, Fort Madison), 1864, 1-3; ibid., 1869, 5-7, 13-14; ibid., 1871, 6-7; Laws of Iowa, 1864, 77; ibid., 1868, 143-44; Iowa House Journal, 1864, 336-41; Walker, "History of Fort Madison Penitentiary," 42-45; D. B. Smith, Two Years in the Slave-Pen of Iowa (Kansas City, 1885), 14. 
The first prisoner entered the penitentiary at Fort Madison on September 22, 1839. The number of prisoners did not rise above 9 until 1854, but then jumped to 123 by 1859 due in large part to the state's dramatic population growth during those years. The number dropped during the Civil War, then increased again after the war to 402 by 1877 . The suspension of the death penalty from 1872 to 1878 had little effect on the overall numbers, but the federal government began adding its prisoners to Iowa's penitentiary by 1864 . Most of the prisoners were committed for murder, burglary, or larceny. Because new counties lacked adequate facilities to house short-term prisoners, the warden in 1864 noted prisoners serving from 30 days to six months. By 1878 , the average sentence was $2 \frac{1}{2}$ years. Few females, rarely more than five or six even as late as the late 1870 s, remained at Fort Madison. In 1884, the state moved the three remaining female inmates to the Additional Penitentiary at Anamosa. Until 1868, the state penitentiary held children as young as twelve; and even as late as the 1880s and 1890s, it maintained inmates as young as fourteen. ${ }^{10}$

A myriad of rules governed the prisoners' every move, dressed them in identifying uniforms, enforced silence during almost all occasions, isolated them in individual cells when not working, eating, or attending religious exercises, and until late in the century excluded them from pastimes except reading books from the prison library. Transgression of these rules brought special penalties, including shaven heads, the ball and chain, and, until 1869 , flogging. In the 1870 s, solitary confinement replaced such punishments in most cases, even though cells specifically designated for that purpose did not exist until after 1886. The absence of secure walls until the 1850s reinforced the Auburn system's emphasis on corporal punishment and restraints such as the ball and chain and collar as means of maintaining order, enforcing discipline, and preventing escape. In 1880 penal authority Enoch Wines confirmed that Iowa's sys-

10. Warden's Report, Fort Madison, 1864, 13; ibid., 1883, 6; Fred N. Watts, Iowa State Penitentiary, 1839-1965 (Fort Madison, 1965); Haynes, Iowa Prison System, 14-15; Walter Lunden, Crime in Iowa (Ames, 1966), 115. On the suspension of the death penalty in Iowa, see Richard Acton, "The Magic of Undiscouraged Effort: The Death Penalty in Early Iowa, 1838-1878," Annals of Iowa 50 (1991), 721-50. 


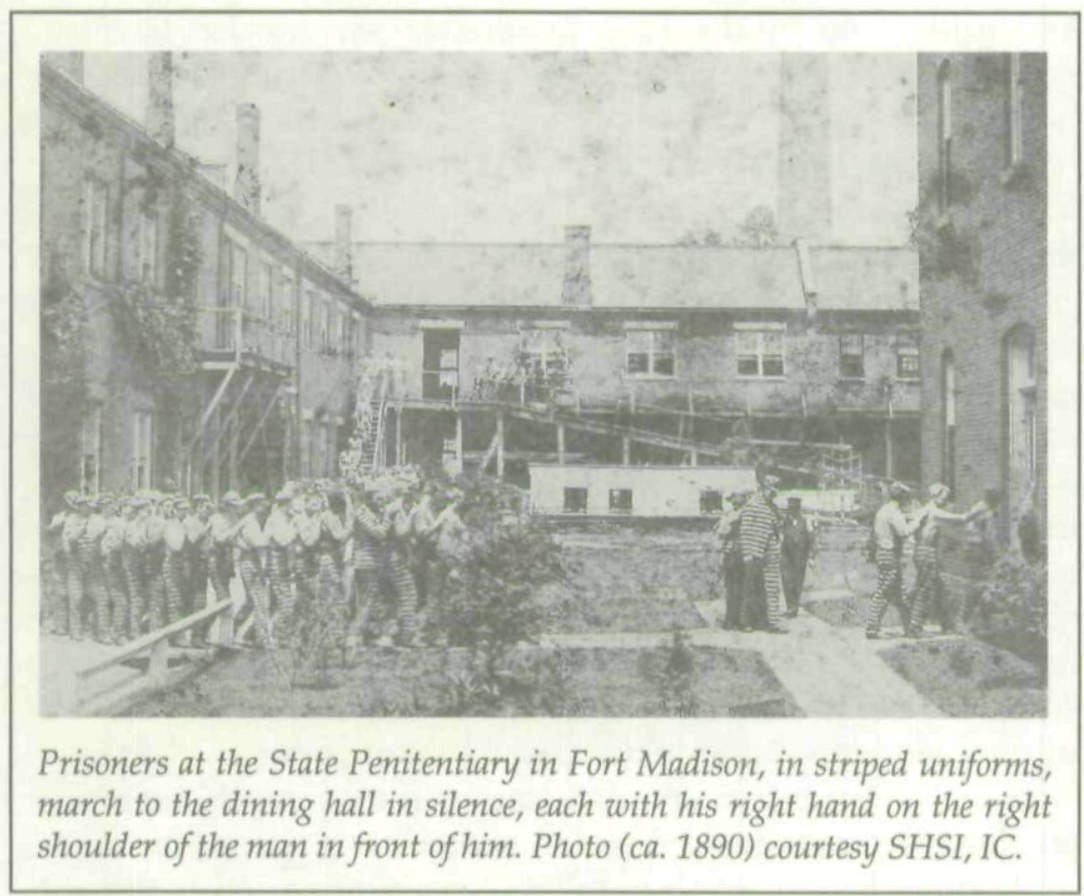

tem of discipline was well within the penal mainstream when he commented that Iowa "is wide awake on the issue of prison discipline and reform. It is one of the banner states of the Union in its penitentiary system."11

GRADUALLY, the State of Iowa altered its approach to discipline and reform. In 1857 the legislature allowed for reduction of sentences for good behavior. And after Warden S. H. Craig attended the National Prison Reform Congress in 1873, he claimed to be striving to replace physical discipline with "appeals to reason and conscience," and to emphasize rewards for good behavior rather than punishment for infractions of rules.

11. Warden's Report, Fort Madison, 1868, 11; ibid., 1869, 9-11; ibid., 1871, 11-15; ibid., 1874, 10-14; ibid., 1875, 17-19; Journal of the Iowa Territorial Council, 1839, 179; ibid., 1842, 48, 200; ibid., 1843, 20; ibid., 1846, 51-54; Board of Inspectors, Report, 1858, 10; Haynes, Iowa Prison System, 12; Enoch Wines and Theodore Dwight, The State of Child Saving Institutions in the Civilized World (Cambridge, 1880), 178. 
Also influenced by the 1873 conference, the warden began to separate hardened criminals from first-time offenders. ${ }^{12}$

These reforms were part of a larger penal reform movement that began in the early 1870s, when the National Conference on Penitentiary and Reformatory Discipline created a list of principles to guide the reformation of state prisons. Those principles continued to guide corrections practices nationwide until the conference's successor, the American Prison Association, revised them in the 1970s. The hallmark of this reform movement was indeterminate sentencing. Instead of fixed sentences for each prisoner, the length of the sentence was to depend on the time required for successful rehabilitation. Thus, reform rather than punishment became, theoretically at least, more firmly established as the goal of imprisonment. This reform movement was significant; although many of the reforms articulated as part of the movement had been advanced earlier, they had never been fully implemented into a successful prison program. Similarly, while American prisons partially adopted the new reforms, they failed to integrate them fully into their existing programs. ${ }^{13}$

Another key principle of the reform movement was that different types of offenders should be housed in separate prisons. Overcrowding at the Fort Madison penitentiary, along with the physical barriers to expanding it, forced legislators to act on that principle by establishing the Additional Penitentiary at Anamosa in 1872. The act establishing the Additional Penitentiary authorized the construction of a prison to house five hundred inmates. To curtail costs, the state purchased a nearby quarry and used prison labor and stone from the quarry to construct the prison. ${ }^{14}$

12. Walker, "History of Fort Madison Penitentiary," 57; Warden's Report, Fort Madison, 1871, 12; ibid., 1874, 18; ibid., 1877, 55; ibid., 1880, 9; ibid., 1887, 8.

13. American Correctional Association, The American Prison from the Beginning: A Pictorial History (n.p., 1983), 67-73; Harry Elmer Barnes, The Story of Punishment: A Record of Man's Inhumanity to Man (Montclair, NJ, 1973), 145-46; Miriam Allen De Ford, Stone Walls: Prisons from Fetters to Furloughs (Philadelphia, 1963), 75-76; McKelvey, American Prisons, 67-68, 78-79, 88-93; Frederick Wines, Punishment and Reformation: A Study of the Penitentiary System (New York, 1910), 193-99.

14. Laws of Iowa, 1872, 49-52; Board of Commissioners of the Additional Penitentiary, Report, 1874, 7; Zumbrunnen, "White Palace of the West," 90; Haynes, Iowa Prison System, 12; John E. Briggs, History of Social Legislation in Iowa (lowa City, 1915), 79. 
In May 1872 the Board of Commissioners visited Sing Sing in New York, the Illinois State Penitentiary at Joliet, and the state penitentiaries in Indiana, Ohio, Pennsylvania, New Jersey, Massachusetts, and Michigan to investigate their physical design as well as their programs. In their 1874 report, they recommended the Wethersfield model, with a multistoried central building containing the warden's residence and necessary services flanked by two cellhouses along the front of the complex and a row of industrial buildings behind. The typically monumental, fortress-like Gothic or Romanesque Revival prison architecture, with its massive outer walls and buildings, crenellated turrets and towers, heavy projections, and tall, narrow openings, communicated the permanence, strength, and authority of the state and displayed an austere and forbidding mien to both prisoners and the outside community. ${ }^{15}$

In 1873 the Additional Penitentiary received 20 prisoners from the State Penitentiary in Fort Madison. The numbers grew slowly to a peak of 625 in 1897 . Although the state established separate institutions for boys, girls, women, and the criminally insane during those years, these groups were separated from male prisoners only slowly. As late as the 1890s, for example, the Additional Penitentiary accepted inmates as young as age eleven even though the state had established the Boys Reform School in $1868 .^{16}$

15. Board of Commissioners of the Additional Penitentiary, Report, 1874, 8, 46; Lori Erickson, "Anamosa's Landmark in Stone," Iowan 38 (Spring 1990), 22-27; Torsten Eriksson, The Reformers: An Historical Survey of Pioneer Experiments in the Treatment of Criminals (New York, 1976), 62-68; McKelvey, American Prisons, 16, 28. William Foster, a prominent Des Moines architect, designed the prison and supervised construction in 1872. Board of Commissioners of the Additional Penitentiary, Report, 1873, 14, 46. He continued to provide plans and guidance for the project through 1895. His successors, J. Frank Barnes (1895-1898), H. F. Liebbe (1898-1927), and Henry J. Liebbe (1927-1941), continued the style he established.

16. H. M. Remley, "History of the Anamosa Penitentiary," Bulletin of Iowa Institutions 3 (1901), 68. The State of Iowa had separated juveniles under the age of 18 comparatively early. A reform school for both, White's Manual Training School, now mostly demolished, was established near Salem in 1868 . The boys were placed in new facilities at Eldora in 1873. The girls were moved to the Girls Reform School in Mitchellville in 1880. See Douglas Wertsch, "Iowa's Daughters: The First Thirty Years of the Girls Reform School of Iowa, 1869 1899," Annals of Iowa 49 (1987), 77-100. 
In 1884, the state removed female prisoners from the State Penitentiary and placed them in the Additional Penitentiary. Never numbering more than 23 , they were probably separated from the male prisoners in a temporary cellhouse. In 1888, they occupied individual cells in a ward on the first floor of the Department of Criminally Insane. Under the supervision of a matron, they worked, sewing, mending, and washing clothing for the prison. As the legislature cracked down on prostitution, making it easier in 1884 to give prison sentences to those associated with the profession, the women's accommodations became crowded. Following years of agitation by women's groups, the legislature created a separate women's department in 1898. The Female Department was erected outside the main prison with its own yard in 1902. Finally, in 1918, the state erected the Women's Reformatory at Rockwell City. ${ }^{17}$

The Additional Penitentiary also held some inmates classified as "criminally insane." Since the 1820 s, the American public had generally considered mentally ill people as incapable of reason and did not hold them responsible for their criminal acts. However, the degree of mental incapacity required to declare someone criminally insane remained ambiguous. Thus, states did not always recognize the need to place those it deemed insane in separate quarters. By 1904, only five entirely separate prisons for the insane existed nationwide; four more segregated the insane. Iowa was not typical. From 1861 until 1888 it placed its criminally insane in the State Hospital for the Insane at Mt. Pleasant. After 1888, the state placed all of its criminally insane-never more than 32 prisoners-in the Additional Penitentiary's Department for the Criminally Insane. The separation was far from perfect, since the hospital and the Female Department occupied the same building until 1902. Iowa's program for the criminally insane did not follow the usual pattern. The main

17. Warden's Report, Fort Madison, 1868, 14-15; Warden's Report, Anamosa, 1883, 6; ibid., 1895, 60; Visiting Committee, Report, 1884, 6; ibid., 1888, 4-5; ibid., 1890, 4, 6-7; ibid., 1896, 5; Board of Control, Report, 1901, 63-65, 691, 699; ibid., 1903, 1005; Laws of Iowa, 1884, 145-46; ibid., 1898, 95; ibid., 1900, 77-79; ibid., 1907, 197; Haynes, Iowa Prison System, 47-48. For accounts of women in state prisons, see Nicole Hahn Rafter, Partial Justice: Women in State Prisons, 1800-1935 (Boston, 1985); and Anne M. Butler, Gendered Justice in the American West: Women Prisoners in Men's Penitentiaries (Urbana and Chicago, 1997). 


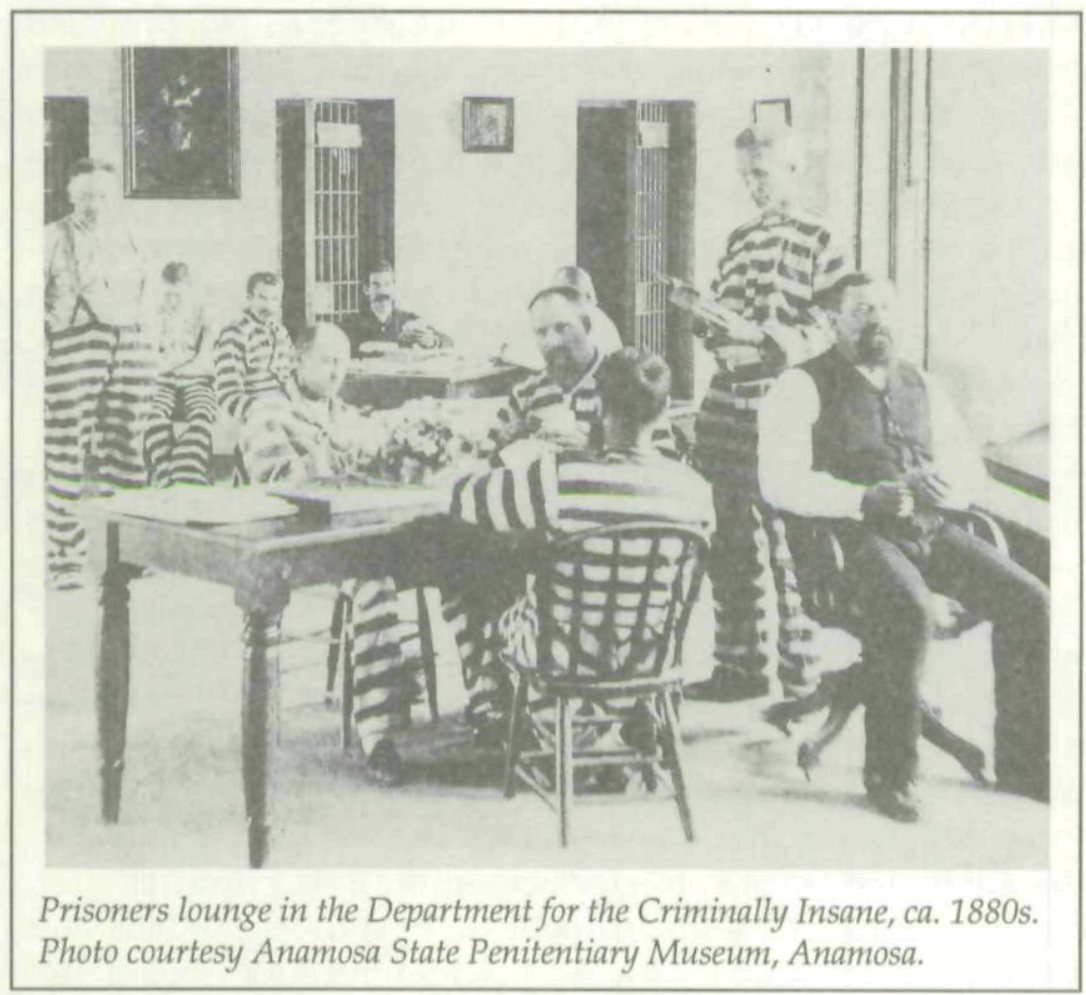

goal was to protect society from the criminally insane. Iowa's program included three hours of outside exercise in the courtyard as well as amusement through games and occupation at simple maintenance tasks. On the other hand, the facility failed to introduce other contemporary treatments for the insane such as those used at the State Hospital for the Insane at Mt. Pleasant. Thus, Iowa was among the earliest states to deal separately with the criminally insane, but its programs failed to meet the standards of the period. ${ }^{18}$

18. Warden's Report, Fort Madison, 1864, 15; Warden's Report, Anamosa, 1884, 6; ibid., 1889, 16; Visiting Committee, Report, 1890; Board of Control, Report, 1903, 1004-5; Gregory Calvert, "A Short History of the Mental Health Institute at Mt. Pleasant" (thesis, Iowa Wesleyan College, 1971). 
ALTHOUGH THE REFORM MOVEMENT had provided the prevailing theory in corrections since the 1840s, the Auburn prison system continued to guide prison life at both of Iowa's state prisons through the nineteenth century in spite of the reform efforts. The prisons strove to reform prisoners through strict and often harsh discipline, religious teachings, moral reform, and hard labor. The absence of recreational activities and stark conditions provided the environment in which the inmate was to realize his errors and modify his behavior. In response to the reform movement, Iowa's prisons did initiate limited educational programs. Generally, however, the prisons continued to focus on punishing negative behavior rather than rewarding good behavior.

Nonetheless, a slow but steady stream of laws promoted reform. In 1857 legislators allowed for the reduction of sentences for good behavior. In 1878 they expanded the definition of good behavior to include the completion of work beyond the minimum and gave the governor the authority to grant conditional pardons. In 1900 Iowa adopted the mark and grade system advocated by prison reformers in the 1870s. And in 1907, after nearly twenty years of lobbying by prison wardens and chaplains, Iowa finally adopted indeterminate sentencing and created a parole board. Prisoners received a minimum and maximum sentence and gained release within that period upon evidence of reform. ${ }^{19}$

Nationwide, religion played a key role both in prison reform movements and in actual programs to reform prisoners. Throughout the nineteenth century, prison authorities pointed to religion as the primary cause of a prisoner's moral reformation. In keeping with this nationwide emphasis, the 1839 act creating Iowa's State Penitentiary provided for the hiring of a part-time minister. By 1843, inmates could attend religious services on alternating Sundays, and Bibles were placed in each

19. Laws of Iowa, 1857, 82; ibid., 1878, 172; ibid., 1907, 193-97; Warden's Report, Fort Madison, 1857, 5; Board of Control, Report, 1899, 115; ibid., 1901, 656; Haynes, Iowa Prison System, 59; T. P. Hollowell, "Some Iowa Criminal History," Iowa Bulletin of State Institutions 24 (1922), 135-37; "History of the Iowa Board of Control," 1942, State Archives; G. S. Robinson, "Penal Reforms," Iowa Journal of History and Politics 3 (1905), 558-61. 
cell. Apparently these services were discontinued for a time, but they had been reinstated by the 1850 s. The prison added a Sunday school and Bible class by 1858 , and pastoral consultation in individual cells occurred at least by 1860 . About 12 to 15 percent of the inmates reportedly attended characteristically evangelical social meetings in 1875 . After 1875, a full-time chaplain served the prison, but other religious groups, including temperance organizations, occasionally presented programs at the prison. All of these religious activities provided moral guidance and emphasized the need to acknowledge one's crime, repent, and seek redemption. ${ }^{20}$

With some exceptions, the services offered at the Additional Penitentiary paralleled those at the State Penitentiary. In 1876 a female teacher and religious leader, Anna C. Merrill, joined the local clergy who had been serving part-time previously. She led the Sunday services, with occasional visits from the local clergy, established a Sunday school and Sunday morning prayer meeting or social meeting, and visited prisoners in their cells. She was listed as "teacher and librarian" until 1885, when she filed a report as "prison chaplain." The next year a visiting committee reported to the legislature that "a common complaint of prisoners as well as the citizens of Anamosa is, that the prison chaplain is by reason of her sex unqualified to discharge the duties of the office in a satisfactory manner." She was replaced by 1887 . After 1895 , the prison chaplain provided separate services for female prisoners and added a prison choir. Volunteers from the Women's Christian Temperance Union and other religious groups gave presentations at the prison. All aspects of the religious program were devoted to the "moral welfare" of the participants through the confession of their act and instruction for proper direction. ${ }^{21}$

20. Journal of the Iowa Territorial Council, 1843, 20; ibid., 1846, 53; Iowa Territorial House Journal, 1846, 270; Laws of Iowa Territory, 1839, 368; Board of Inspectors, Report, 1858; Warden's Report, Fort Madison, 1857, 5-6; ibid., 1859, 36; ibid., 1864, 28-29; ibid., 1870, 11-12; ibid., 1871, 13; ibid., 1874, 41; ibid., 1875, 3-4; ibid., 1880, 53; ibid., 1881, 36; ibid., 1885, 108-9; ibid., 1895, 42-44.

21. Warden's Report, Anamosa, 1875, 8; ibid., 1877, 11, 27-28; ibid., 1879, 8, 31; ibid., 1881, 33-34; ibid., 1885, 26-28; ibid., 1887, 35-36; ibid., 1889, 11-12; ibid., 1891, 26-28; ibid., 1893, 21; ibid., 1895, 55-60; Visiting Committee, Report, 1886, 3-4. 
Through much of the prisons' history, the chaplains directed whatever education programs existed, giving this major reform emphasis a religious tone. The State Penitentiary initiated the prison school as a cell study program under the chaplain's direction by 1868 . Eventually the prison set aside space for more formal classes. The training of illiterate inmates (rather than training prisoners for employment once they were released from prison) remained the focus of the program through the last quarter of the nineteenth century. In 1851 the legislature established a rather sparse prison library. By 1882, selections included moral and religious works, biographies, histories, and works of science as well as magazines and newspapers. ${ }^{22}$

Anna Merrill began the educational program at Anamosa in 1878. By 1888 , the prison required all illiterate inmates to attend. The program presented basic educational skills and moral instruction, although by 1890 more advanced students were allowed to take materials to their cells for additional study. Mrs. Merrill began assembling a library in 1876. At both institutions, the gate fee charged to visitors was a significant source of income and was used to build the libraries. By 1878 the visitor's fee had purchased 400 volumes of religious works, histories, travel, adventure, and fiction for the Anamosa library. It grew to 2,700 volumes by $1890 .^{23}$

In addition to their roles as religious and moral advisers and educators, chaplains were the prison system's main support for prisoners as they reentered society. Chaplains informally and sporadically provided guidance and helped discharged prisoners find employment. Otherwise, there was little support for prisoners upon release. In 1872 the prisons began furnishing each discharged prisoner with transportation to any place in the state, along with a suit of clothing and three to five dollars.

22. Board of Inspectors, Report, 1858; Warden's Report, Fort Madison, 1857, 5-6; ibid., 1868, 13, 38-39; ibid., 1871, 14; ibid., 1875, 3-4, 21; ibid., 1877, 13, 50; ibid., 1881, 37-38; ibid., 1883, 9, 64-65; ibid., 1887, 68-69, ibid., 1889, 40-48; ibid., 1897, 37-38; Margaret Bennett, "History of Iowa State Penitentiary, Fort Madison," pamphlet, State Archives; Walker, "History of Fort Madison Penitentiary," 29.

23. Examining Committee, Report, 1874, 7; Warden's Report, Anamosa, 1877, 11; ibid., 1879, 8, 31; ibid., 1881, 33-34; ibid., 1885, 27-28; ibid., 1887, 37-38; ibid., 1889, 13; ibid., 1891, 28-29; ibid., 1893, 21-22; ibid., 1895, 56. 
Several wardens advocated the formation of a prisoners' aid association. The legislature finally provided minimal funding for such an organization in 1886, but the voluntary organization lasted only until 1890. Another such association, the Howard Association, formed between 1902 and 1904. Because of limited staffing, those organizations - and even the parole board after it was organized-provided little real guidance except when discharged prisoners experienced difficulties that were brought to the wardens' attention. The problem persisted well into the twentieth century. ${ }^{24}$

HARD LABOR joined religious and moral reform and strict discipline as a third key element of the program at both prisons. When the state established the penitentiary at Fort Madison in 1839 , it sentenced its prisoners to hard labor to punish them and to teach them industrious habits. With some modification, this concept of labor remained intact through the end of the century. When the legislature created the Additional Penitentiary, it specified that hard labor should be used to reform as well as punish inmates. But by then, corrections officers were already focusing on developing skills and habits that would encourage suitable employment after the inmates' release from prison. Still, in this area, as in so many other aspects of prison reform, financial considerations prevented the full implementation of reform ideals.

A primary work project for prisoners was constructing their prisons. Until 1846, despite objections from local residents, prisoners also worked outside the prison, cutting timber, doing agricultural work, digging cellars in the adjacent community, and performing other casual labor. By 1841, some prisoners were working in the prison's own cooper and blacksmith shops, though scarce materials and crowding limited production. The

24. Hollowell, "Some Iowa Criminal History," 134-35; Iowa Territorial House Journal, 1846, 270-71; Laws of Iowa, 1857, 82; ibid., 1872, 59-60; Board of Inspectors, Report, 1858; Warden's Report, Fort Madison, 1873, 5; ibid., 1875, 60; ibid., 1881, 38-39; ibid., 1889, 47-48; ibid., 1891, 50; Board of Control, Report, 1901, 679; ibid., 1903, 9, 998-99; Fred E. Haynes, "Glenn C. Haynes," Palimpsest 23 (1942), 311, 333; Briggs, History of Social Legislation, 103-4; Osborne Association, Inc., Handbook of American Penal Institutions and Reformatories (New York, 1938), 19; Haynes, Iowa Prison System, 52. 


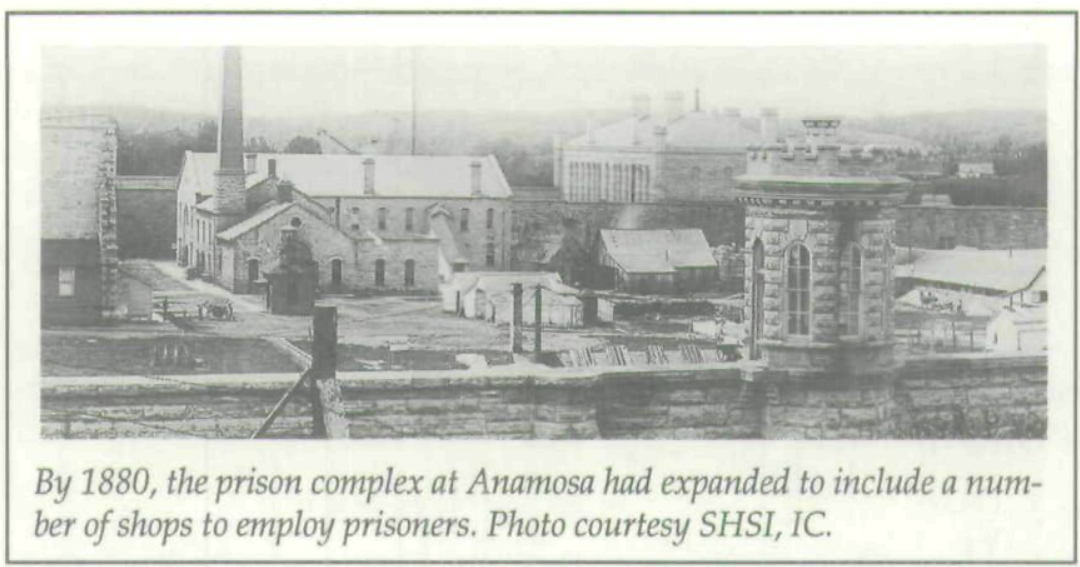

construction of more permanent shops in 1843 improved work conditions and permitted the addition of shoe making. The warden sold their products on the open market. ${ }^{25}$

These crafts and outside employment returned little profit to reduce the prison's debt, so the state reluctantly leased the prison to John Cohick between 1846 and 1849. Cohick acquired complete management of the prison, its inmates, and their labor, from which he was to profit. When that system proved unsatisfactory, the state inaugurated the contracting of prison labor in 1853. Over the next couple of decades, the prison entered into various contracts to manufacture buggies, harnesses, agricultural implements, furniture, coffins, boots, shoes, horse collars, saddles, and buttons. The manufacturers used state buildings located inside the prison walls. ${ }^{26}$

25. Laws of the Territory of Iowa, 1839, 366-67; ibid., 1840, 213; ibid., 1846, 68; Journal of the Iowa Territorial Council, 1841, 272-74, 289-91; ibid., 1842, 198-203; ibid., 1843, 116, 191-92; ibid., 1846, 51, 268; Walker, "History of Fort Madison Penitentiary," 27, 51.

26. Jean B. Kern, "Warden and Warrior," Palimpsest 29 (1948), 189; Walker, "History of Fort Madison Penitentiary," 52-55; Watts, Iowa State Penitentiary, 10; Donald W. Brookman, "Prison Labor in Iowa," Iowa Journal of History and Politics 32 (1934), 131; Iowa Territorial House Journal, 1846, 272-73; Laws of the Territory of Iowa, 1846, 655-57; Laws of Iowa, 1853, 37; ibid., 1860, 106; ibid., 1862 (extra session), 13; Iowa House Journal, 1855, 24-25; Board of Inspectors, Report, 1859, 7-8, 27-28; Warden's Report, Fort Madison, 1869, 18-25; ibid., 1871, 15-18; ibid., 1874, 22-27; ibid., 1875, 30-43; ibid., 1877, 15-16, 21-35, 57-63; ibid., 1880, 15-27; ibid., 1885, 76; ibid., 1889, 8; ibid., 1895, 7-8; ibid., 1897, 9; Contract with Fort Madison Chair Co., 1888, 1896, Iowa Secretary of State Papers, State Archives. 
The inmates' competition with local labor became a concern when the prison was established and again near the end of the century. As early as 1841, investigating committees noted the detrimental effect of prison labor on local artisans and day laborers. They also observed that contracting companies employed prisoners to make a profit, not to reform prisoners. Such employment did not guarantee humane treatment. On the other hand, those same committees noted that the absence of work for prisoners led to disharmony and a failure to teach industrious habits. In 1887 Warden G. W. Crosley at the Fort Madison penitentiary noted that the abolition of contract labor caused such difficulties in New York. But he also warned that such methods as the state-use system proved financially unsuccessful. ${ }^{27}$

During the depressions of the early 1870 s and 1880 s, labor unions and manufacturers competing with prison contractors accused the prisons of unfair practice. During the 1880s, Iowa, like most other northeastern and midwestern states, established commissions to investigate contract prison labor. New York, New Jersey, and Illinois prohibited leasing and contracting in their prisons by 1890, and federal legislation ended contracting in federal prisons in 1887. More industrialized states began to turn to piece-price and state-use systems of labor by the mid1880s. (Under the piece-price system, manufacturers paid a set price for the finished product rather than for the prisoner's labor. Under the state-use system, goods produced by prisoners were not sold on the open market but were available only to government agencies and institutions. Competing manufacturers preferred the latter system, but it provided less profit for the state and consumed much of the warden's time.) In Iowa, contracting dominated prison labor at the State Penitentiary into the twentieth century. However, in 1900 the Iowa legislature, under pressure from the Iowa Federation of Labor, did prohibit

27. Journal of the Iowa Territorial Council, 1845, 190-91; ibid., 1846, 52, 56; Iowa Territorial House Journal, 1846, 273-74; Board of Inspectors, Report, 1859, 6; Warden's Report, Fort Madison, 1873, 14-16; Visiting Committee, Report, 1882, 5; Warden's Report, Fort Madison, 1887, 12; ibid., 1889, 8, 48; Walker, "History of Fort Madison Penitentiary," 27-28, 55. 
the manufacture of pearl buttons at the State Penitentiary and butter tubs at the Additional Penitentiary. ${ }^{28}$

The conflicting goals of reforming prisoners and securing adequate financial support for prisons remained an issue through the first quarter of the twentieth century. Making prisons self-supporting was one objective of contract labor. Indeed, by the 1870 s, the financial support offered by prison manufacturing contracts became a more important consideration than the reformatory nature of prison labor. In keeping with that consideration, the selection of Anamosa as the site of the Additional Penitentiary was due in large part to the presence of limestone quarries nearby that could support the prison. State legislators believed that the State Penitentiary at Fort Madison had not achieved self-sufficiency because of the unprofitable contracts available to the state at that location. They pointed to the examples of prisons at Sing Sing, New York, and Columbus, Ohio, which had significantly reduced prison construction costs by using inmate labor to quarry and dress stone from nearby, state-owned quarries. Promoters of the Anamosa site also noted that stone from state quarries could be used in other state construction sites. Any profits from the sale of stone could be used to support the Additional Penitentiary. Such state-use work and maintenance tasks, including blacksmithing, carpentry, and some mechanical engineering, remained the primary labor engaging the prisoners at the Additional Penitentiary until $1898 .^{29}$

The State Penitentiary at Fort Madison also employed its inmates in some state work. Prior to 1900, such work provided goods and services necessary for the operation of the prison. In addition to prison construction, it included cooking, washing, and other repair and maintenance activities; the provision and

28. Miriam Zelda Langsam, "The Nineteenth Century Criminal: Ideologies and Institutions" (Ph.D. thesis, University of Wisconsin-Madison, 1967), 172-73, 176-78, 211-14; McKelvey, American Prisons, 86, 111, 117-28, 136; Brookman, "Prison Labor in Iowa," 124-25, 134; De Ford, Stone Walls, 103; Laws of Iowa, 1900, 96-97.

29. Zumbrunnen, "White Palace of the West," 89; 1872, 49-52; Examining Committee, Report, 1874, 13-15; Visiting Committee, Report, 1878, 6-7; ibid., 1894, 4-5; ibid., 1896, 5; Briggs, History of Social Legislation, 79; Brookman, "Prison Labor in Iowa," 130. The limestone quarry site is still extant and includes evidence of earlier quarry operations. 


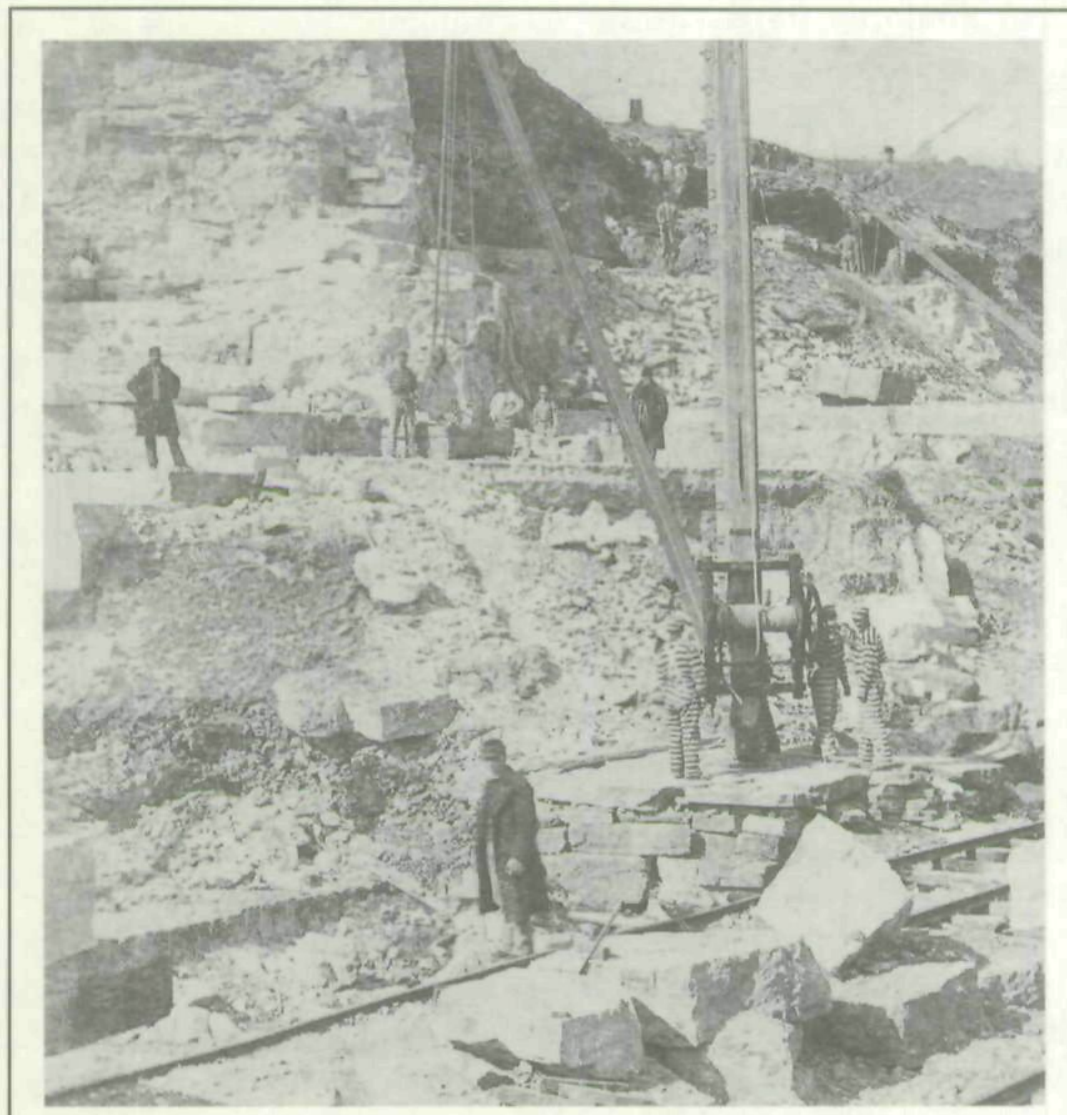

Guards watch over prisoners (in striped uniforms) working in the rock quarry at Anamosa, ca. 1880s. Photo courtesy SHSI, IC.

mending of shoes and clothing by about 1859; and the making of soap by 1881 . Inmate labor intermittently produced some of the food consumed in the prison. By 1841, inmates cleared a garden for this purpose. Although a barn existed just west and south of the prison gate by 1900 , agriculture received little emphasis until after that date. ${ }^{30}$

30. Journal of the Iowa Territorial Council, 1841, 273, 289; ibid., 1845, 191; Board of Inspectors, Report, 1859, 22; Warden's Report, Fort Madison, 1880, 4; ibid., 1881, 4; J. W. Campbell, "Fragmentary History of the Fort Madison Penitentiary," Bulletin of the Iowa Board of Control 2 (1900), 171-90. 
Although state law expressly prohibited contracting at the Additional Penitentiary at Anamosa, contracting continued at the State Penitentiary at Fort Madison into the twentieth century. In both cases, however, the state continued to view prison labor primarily as a means of occupying prisoners and defraying the cost of their keep. ${ }^{31}$

IN 1898 Iowa's state penitentiaries came under the administration of the State Board of Control. Prior to that time, each state institution had its own board of trustees, overseen by the governor and the executive council. As the number of state institutions and their portion of the state budget increased during the nineteenth century, this system came to be seen as cumbersome. Responding to complaints of large expenditures at some of the institutions, rumors of mismanaged funds, favoritism in the purchase of supplies, and antagonism between the various boards of trustees and the state legislature, the General Assembly appointed an investigating committee in 1897 . That committee recommended substituting a single central board for the existing 13 boards with a total of 75 members. That central board could ensure uniform purchasing and record keeping, promote more intelligent and economical management, and minimize political partisanship. The Board of Control of State Institutions, created by the General Assembly, assumed control of state institutions on July $1,1898 .{ }^{32}$ As the population in Iowa's corrections system increased dramatically over the next decadeand-a-half, the Board of Control, working with the legislature and prison officials, responded to a new wave of progressive prison reform with a series of significant changes.

A key element of Progressive Era prison reform was a focus on individual prisoners' development. Extending the limited separation of prisoners begun under the Auburn system, Progressive Era reformers advocated the classification of prisoners,

31. "History of the Iowa Board of Control."

32. Ibid.; McKelvey, American Prisons, 71-74, 150-53, 175, 240-41; Haynes, Iowa Prison System, 19-29; Laws of Iowa, 1898, 62; Board of Control, Report, 1900, 1-2; Glenn Haynes, The American Prison System (New York, 1939), 220-22; Brookman, "Prison Labor in Iowa," 134. 
with indeterminate sentencing and separate treatment for each classification. Efforts to reform prisoners would focus on the young, first offender, who would be separated from the influences of the general prison population to accomplish reform. Because the time necessary for change varied from prisoner to prisoner, indeterminate sentencing and parole became important elements of the more individualized progressive program. And, unlike the Auburn system, reform was to be accomplished through military drill, educational and vocational training oriented more toward the prisoner's aptitude, and strict discipline with positive rewards for good behavior rather than relying solely on hard labor or religious conversion. ${ }^{33}$

In response to this progressive reform movement, the Board of Control began pressing in 1900 for legislation to create a reformatory for young male offenders. ${ }^{34}$ In 1905 the Iowa legislature appointed an investigating committee to examine the reformatories in other states, including the Elmira Reformatory in New York. By that time, indeterminate sentencing governed reformatories in 13 states, and six states used a parole system. In 1907, Iowa's prison reform law designated the prison at Anamosa as the Men's Reformatory for first offenders between the ages of 16 and 30 . The law provided for indeterminate sentencing and parole for prisoners at both the Reformatory and the State Penitentiary. The law also called for an upgrading of educational programs and a prison labor system that would offer

33. McKelvey, American Prisons, 12, 234-38, 263-64; American Correctional Association, American Prison, 126-30, 134-35, 151, 156-57; LaMar T. Empey, American Delinquency: Its Meaning and Construction (Homewood, IL, 1982), 37476; Rafter, Partial Justice, 53-54; David J. Rothman, Conscience and Convenience: The Asylum and Its Alternatives in Progressive America (Boston, 1980), 48-53.

34. Leaders in Iowa penology and state government had recognized the need for a reformatory for young men since the 1870 s. In 1876 Governor Carpenter suggested the use of the penitentiary at Anamosa for young men committing first offenses. Governor Gear presented a similar proposal in 1880 . N. N. Jones, the warden at the State Penitentiary, in his reports to the Board of Control from 1898 to 1900 , strongly urged the legislature to create a young men's reformatory with a graded system of discipline and to include in that legislation indeterminate sentencing, parole, and provisions for industrial and educational training. Warden Hunter of the Additional Penitentiary supported the Board of Control after it took up the cause. Cyrus C. Carpenter, Biennial Message, 1876, 19-20; Board of Control, Report, 1900, 120, 901; ibid., 1902, 65-66, 965, 996; ibid., 1904, 41, 997-98; Robinson, "Penal Reforms," 553-61. 
vocational training. Unfortunately, the legislature initially appropriated little money to implement these changes. The continued presence of other classes of prisoners, including the Women's Department and the Department for the Criminally Insane, further inhibited reform efforts. ${ }^{35}$

A MAJOR IMPETUS for prison reform in Iowa in the early years of the twentieth century was the Cosson Report of 1912 . The report was the result of a detailed investigation of Iowa's prison facilities undertaken in 1911 in response to prisoner complaints against the warden at the Iowa State Penitentiary. What began as an examination of prison facilities, programs, personnel, and inmates at Fort Madison eventually extended to other penal institutions and to an examination of other state prisons in Illinois, Indiana, and Ohio, as well as the federal penitentiary at Leavenworth, Kansas, and the Elmira Reformatory, Auburn Penitentiary, and the Agricultural and Industrial School in New York. The study gave Iowa leaders in penology a clear understanding of contemporary practices. The report assigned responsibility for the problems at Fort Madison to the inadequacies of the system rather than to the personalities involved. A far-reaching document, the Cosson Report stressed the need to maintain records of inmates' physical and mental abilities. It also recommended modernization of out-of-date facilities at Fort Madison and the creation of trade schools and the strengthening of the educational system at Anamosa. Finally, it recommended the classification, segregation, and, most significantly, the individualized treatment of prisoners, a key element of progressive prison reform. ${ }^{36}$

Contract labor was a key concern of the report. The committee dismissed prisoners' complaints concerning denial of parole because of their employment in prison contracts, employment of prisoners when physically unable, abuse of inmates by con-

35. Laws of Iowa, 1907, 192-97; Board of Control, Report, 1909, 13-14; Haynes, Iowa Prison System, 32-34.

36. George Cosson et al., The Report of the Committee Appointed to Investigate the Character of the Warden and the General Management of the Iowa Penitentiary at Fort Madison Together with a Report Concerning the Jail System of Iowa with Recommendations (Des Moines, 1912); "History of the Iowa Board of Control." 
tractors, the warden's interest in contracts, and the passage of letters and contraband by the contractors' employees. The report nonetheless condemned contract labor programs at the State Penitentiary and Men's Reformatory and recommended the withdrawal of private interests from the corrections system. Because of the control contractors had over prison labor, the report described it as a form of involuntary servitude. The contractors' motives, it charged, were purely economic without interest in the prisoners' welfare or training. The report favored prison labor outside the walls at public works or on farms for some classes of prisoners. It cautioned against retaining prisoners beyond their time of release because of their labor, and recommended that prisoners be paid at a standard rate of pay with deductions taken for maintenance. ${ }^{37}$

The state struggled over the succeeding decades to rectify the problems identified by the Cosson Report and kept in the public eye by the progressive prison reform movement. To accomplish the report's recommendations, the legislature established a special tax levy in 1913 to support the development of state-use industries, the construction of buildings, and the purchase of equipment necessary to support them. Subsequently, the Board of Control authorized limited funds to establish the necessary state-operated prison industries and to purchase lands for prison farms to employ honor prisoners. In 1915 the legislature ended contract labor, specified that prison labor was to be conducive to the teaching of useful trades and the moral development of the inmates, and required just compensation for labor. ${ }^{38}$

Although the investigation leading to the Cosson Report had been prompted by complaints about prison labor policies at the State Penitentiary in Fort Madison, the state's actual efforts to reform those policies began at the Men's Reformatory. Prison

\section{Ibid.}

38. Ibid.; Board of Control, Report, 1912, 31-34; ibid., 1914, 18; ibid., 1916, 43; ibid., 1920, 15-17; ibid., 1922, 29; Laws of Iowa, 1913, 21-22; ibid., 1915, 332-34; Brookman, "Prison Labor in Iowa," 134; Briggs, History of Social Legislation, 211; "History of the Iowa Board of Control"; Haynes, Iowa Prison System, 39-43, 5758; Jacob A. Swisher and Dorothy Schaffter, "The Legislation of the Forty-second General Assembly of Iowa," Iowa Journal of History and Politics 25 (1927), 51718. 
labor was, theoretically at least, an important part of the reform program at the Men's Reformatory, contributing both to the inmate's personal work habits and to his training in specific vocational skills. Despite legislative support, however, financial support for the prison remained a primary consideration, reducing the level of vocational training. As construction occupied fewer prisoners, the Board of Control entered into a contract to produce butter tubs, pails, and barrels. After organized labor and manufacturers objected, the legislature ended the contracts, but the prison continued the operation on a stateaccount basis, selling the goods to private firms. In 1923, the Men's Reformatory switched to the manufacture of aprons, employing about 450 inmates on a piece-price basis. Legislators again responded to complaints from manufacturers and labor and in 1933 prohibited the sale of prison-made products across state lines. ${ }^{39}$

After the legislature prohibited contract work in 1915, the state increased the number and production of state-use industries. It expanded its quarrying operations at the Reformatory, increasingly selling building stone and gravel to other state institutions and road districts. ${ }^{40}$ Inmates ceased breaking the stone by hand into specified sizes after the state installed a 40 -ton stone crusher in 1911. The state also expanded its state-use printing and binding operations, first established in 1898, to produce the prison newspaper and letterhead. By 1908, the printing department was serving other institutions. The Reformatory also began a sheet metal industry to produce metal roofing and gutters. It added aluminum products such as eating utensils and cookware in 1924. The tailor and shoe industries produced goods for the prison as early as the 1880s and continued throughout the period. Women prisoners manufactured many of the sewn goods in the Female Department until 1918; by 1911, male inmates were also employed in this task. From

39. Laws of Iowa, 1900, 96-97; ibid., 1927, 78; ibid., 1933, 72-73; Swisher and Shaffter, "Legislation of the Forty-second General Assembly," 517-19; "History of the Iowa Board of Control."

40. The gravel and stone came from the prison quarry originally established to furnish stone for the prison. That site is still extant and includes the standing remains of the dining hall. 
1927 through 1942 inmates manufactured soap products for prison use and sale to other institutions. Production of license plates and signs began in 1925. The Reformatory also continued to employ prisoners in maintenance activities such as cooking and baking, operating the power house, blacksmithing, carpentry, electrical work, plumbing, repairing vehicles, office work, and construction and maintenance of buildings and lawns. ${ }^{41}$

Even though the town of Anamosa had donated 40 acres of land to secure the prison, agricultural activities remained limited through 1916. In response to the legislature's directive in 1913, the Board of Control began purchasing farmland and expanding farm operations. By 1917, inmates farmed 380 acres of land owned by the state and at least 985 acres of leased land. The state purchased most of that land by 1930. As the Cosson Report recommended, the state also purchased the Martin Flynn farm northwest of Des Moines in 1913 for prisoners to gain farm work experience. The Board of Control ran the farm with inmates from the State Penitentiary from 1915 to 1922 . About 20 honor prisoners from the Reformatory ran it from 1922 to $1935 .{ }^{42}$

Directed by the Cosson Report and mandated by the resulting 1913 legislation, the Reformatory also began to employ its honor prisoners to construct and maintain public works. In 1913 inmates did construction and landscaping work on the Iowa State College campus. They camped in tents and received wages for their work. After the state moved to substitute state-use labor

41. Board of Control, Report, 1900, 974-75; ibid., 1902, 696-97, 704; ibid., 1908, 14; ibid., 1916, 43; ibid., 1920, 16; ibid., 1922, 27-30; ibid., 1924, 25-29; ibid., 1926, 20-22; ibid., 1934, 92; ibid., 1942, 136 (Board of Control Reports after 1931 are published separately); Men's Reformatory, Report to the Board of Control, 1906, 2; ibid., 1912, 11; ibid., 1926, 4; ibid., 1934, 5, 7 (these reports were not included in Legislative Documents but were printed and published separately and are at the State Law Library, State Capitol, Des Moines); Souvenir of the Men's Reformatory (Anamosa, n.d. [1930s]); Osborne Association, Handbook, 31, 38-39; Curtis [no other name given], Five Years at Anamosa by the Editor of the Anamosa Prison Press (n.p., 1899).

42. Board of Control, Report, 1900, 959; ibid., 1902, 700; ibid., 1904, 1010-12; ibid., 1916, 21-24; ibid., 1918, 13-15; Souvenir of the Men's Reformatory, 11, 19; "History of the Iowa Board of Control." The Reformatory continues to operate Farm No. 1, which includes limestone outbuildings erected between 1912 and 1939. Much of the Martin Flynn farm later became incorporated into Living History Farms. 
for contract labor in 1915, Reformatory inmates constructed public highways and buildings at other state institutions. By the 1930 s, the farm and public works programs not only provided a variety of work for prisoners making the transition from the Reformatory back to communities, but also helped to reduce the overcrowded conditions within the facility. Contemporary approaches to corrections treatment, reflected in the Cosson Report, stressed the benefits of outside work, especially farm work, for prisoners' health and mental attitude. ${ }^{43}$

The designation of the Additional Penitentiary at Anamosa as the Men's Reformatory removed most of the younger prisoners from the State Penitentiary at Fort Madison and focused reform efforts at the Reformatory. However, the flurry of progressive legislation in the first decade of the twentieth century-the grading of prisoners by behavior in 1900, indeterminate sentencing and parole laws of 1907, and subsequent legislation governing prison labor-affected the State Penitentiary as well as the Men's Reformatory. Perhaps to a greater degree at the Reformatory, but also at the Penitentiary, the emphasis on strict discipline and behavioral reform declined as rehabilitation primarily through retraining increased in importance. ${ }^{44}$

As at the Men's Reformatory, the reform of prison labor at the State Penitentiary meant a significant expansion of state-use and state-account work. In 1915-the same year that the legislature abolished contract labor and set inmate wages at the level earned by free labor less the costs of maintenance-the State Penitentiary established a large state-account factory that produced chairs and other furniture that it marketed through a private jobber to avoid the stigma of prison-made products. Over the years prisoners at the State Penitentiary produced such goods as rugs, brooms and brushes, mattresses, clothing, shoes, underwear and hosiery, and sanitary supplies. A few honor prisoners worked on state road construction or public works projects. Others worked on farmland the state purchased near

43. Haynes, Iowa Prison System, 42-43; Board of Control, Report, 1915, 18, 38; ibid., 1918, 13; Men's Reformatory, Report to the Board of Control, 1914, 10-11; Swisher and Shaffter, "Legislation of the Forty-second General Assembly," 518. 44. "History of the Iowa Board of Control"; Osborne Association, Handbook, 28; Haynes, Iowa Prison System; Haynes, "Glenn C. Haynes," 305-16, 330-36. 
Fort Madison between 1906 and 1914 or on the Martin Flynn farm northwest of Des Moines. The state also continued to use prison labor to maintain its own facilities, including the power plant, kitchen, yards, and buildings. In the 1930s and into the early 1940s, the state often engaged a large group of inmates in prison construction. In spite of this expanded range of work and the prohibition of contract labor, one piece-price contract managed to survive until 1933 over the protests of manufacturers and labor unions. ${ }^{45}$

Although the emphasis on hard labor as a punishment had clearly diminished and the goal of training prisoners for life outside the prison walls had become more prominent, prison labor continued to serve the goals of occupying inmates and providing financial support for the prisons. The Cosson Report had suggested placing greater emphasis on education and vocational training at the State Penitentiary. The Board of Control belatedly defended its prison industry program by pointing to the training it provided in specific vocations by 1921, but it also continued to emphasize the industries' large contribution to institutional support. An external report in 1938 indicated that the prison still lacked a vocational program. The institution had no employees trained to present such a program, tended to employ prisoners on a single machine for long periods, relied solely on foremen for supervision, and failed to tie its educational programs to vocational training. ${ }^{46}$

THE EDUCATIONAL PROGRAMS that did exist continued to focus almost entirely on providing instruction to illiterate inmates, and their effectiveness in this area was occasionally questioned. A 1928 study reported that 13 of the 60 prisons it studied nationwide failed even to offer literacy courses, most provided little education beyond that, and none offered adequate voca-

45. Cosson, Report; Haynes, Iowa Prison System, 32-42; Board of Control, Report, 1908, 14; ibid., 1912, 31; ibid., 1914, 18; ibid., 1916, 16-17; Men's Reformatory, Report to the Board of Control, 1914, 6-7; Watts, Iowa State Penitentiary, 18-19; Brookman, "Prison Labor in Iowa," 147-48; Swisher and Shaffter, "Legislation of the Forty-Second General Assembly," 517-19; "History of the Iowa Board of Control"; Presidio, May 1964, 8; ibid., December 1966, 20.

46. Osborne Association, Handbook. 
tional programs. Because prisons commonly used inmates or guards as teachers, the quality of teaching remained low. ${ }^{47}$

In Iowa's prisons, education remained the responsibility of the chaplain and selected inmates well into the twentieth century. The State Penitentiary offered night schools that addressed literacy problems only. The state did establish a day school at the Men's Reformatory in 1909, and a trained teacher did eventually assume educational duties. Focusing on the practical areas required for the understanding of trades, the school covered materials in grades one through six. Based on examination results and past education and ability, the Reformatory prescribed a course of study for each student and advanced him by course rather than grade. As the prison population grew and demand increased, the Reformatory again added inmate teachers so that by 1938 three teachers, a superintendent, and twenty inmates staffed the school. Despite its deficiencies, the Reformatory's program did attempt some individualized programming. ${ }^{48}$

At the turn of the century, prison reformers had observed that many inmates committed crimes because they lacked the knowledge, skills, and work ethic to earn a living. The Board of Control, similarly recognizing that inmates needed to gain proficiency in a trade before being released, asked the legislature in 1914 to add training in business and agriculture. Although the legislature did allot funds for buildings and equipment, the prison failed to provide a systematic teaching program in vocations; it relied on foremen rather than instructors to teach many trades; and it did not create circumstances in which an inmate might acquire broad knowledge and skills in a specific vocation. In 1938, an outside investigator noted that, apart from instruction in spelling, grammar and the mechanics of printing provided for those working in the print shop, few prison industries

47. McKelvey, American Prisons, 249, 307; Rothman, Conscience and Convenience, 135-37; Max Grünhut, Penal Reform: A Comparative Study (Oxford, 1948), 117; Gordon Hawkins, The Prison: Policy and Practice (Chicago, 1976), 118-23; Haynes, American Prison System, 120-23.

48. "History of the Iowa Board of Control"; Board of Control, Report, 1900, 97374; ibid., 1902, 697-98; ibid., 1910, 37-38; Men's Reformatory, Report to the Board of Control, 1902, 24; ibid., 1911, 68; ibid., 1912, 7-8, 11, 68; ibid., 1914, 8, 58; ibid., $1916,12$. 
were correlated with course instruction. Those findings repeat the refrain: training did improve in the 1930s but still failed to meet the needs of most prisoners due to understaffing, inadequate facilities, and limited funding. In general, reforms advocated in the 1870s began to take effect in the 1900s, and those promoted at the turn of the century began to be applied in the 1930s. ${ }^{49}$

THE LIFE OF THE PRISONERS at the State Penitentiary and the Men's Reformatory changed only very slowly even after the turn of the century. The prohibition era of the 1920s and the depression of the 1920s and 1930s added to the overcrowding of state prisons, leaving little room for separate spaces needed for the classification of prisoners, adequate medical services, vocational training, and education. With staffs limited in numbers and training, prison chaplains continued to lead the few social programs that did exist.

One notable change, however, was the gradual acceptance of recreational opportunities for prisoners. Before 1900, prisoners had few opportunities for recreation, apart from reading or occasional use of the prison yard (in silence). Recreation was an important element of Progressive Era prison reform proposals. In adopting some of the progressive programs, the Men's Reformatory tended to lead the State Penitentiary by about a decade. In 1898 the warden at the Reformatory began granting freedom of the yard for public holidays. By 1910, most prisoners at both institutions had gained weekly yard privileges and engaged in organized sports, especially baseball. By that time, there were also prison bands, plus an orchestra and choir at the Reformatory, that presented concerts on Sundays and holidays. Visitors' gate receipts funded other concerts, lectures, performances, and, by the 1930 s, movies. ${ }^{50}$

49. Men's Reformatory, Report to the Board of Control, 1912, 8; ibid., 1914, 10, 5860; Board of Control, Report, 1914, 37-39; Osborne Association, Handbook, 39, 44; Haynes, Iowa Prison System, 36-37.

50. McKelvey, American Prisons, 188, 200-201, 267, 294; Board of Control, Report, 1901, 701; ibid., 1903, 1002-3; ibid., 1912, 34; Men's Reformatory, Report to the Board of Control, 1906, 44; ibid., 1912, 6; ibid., 1914, 10, 60-61; "History of the Iowa Board of Control." 


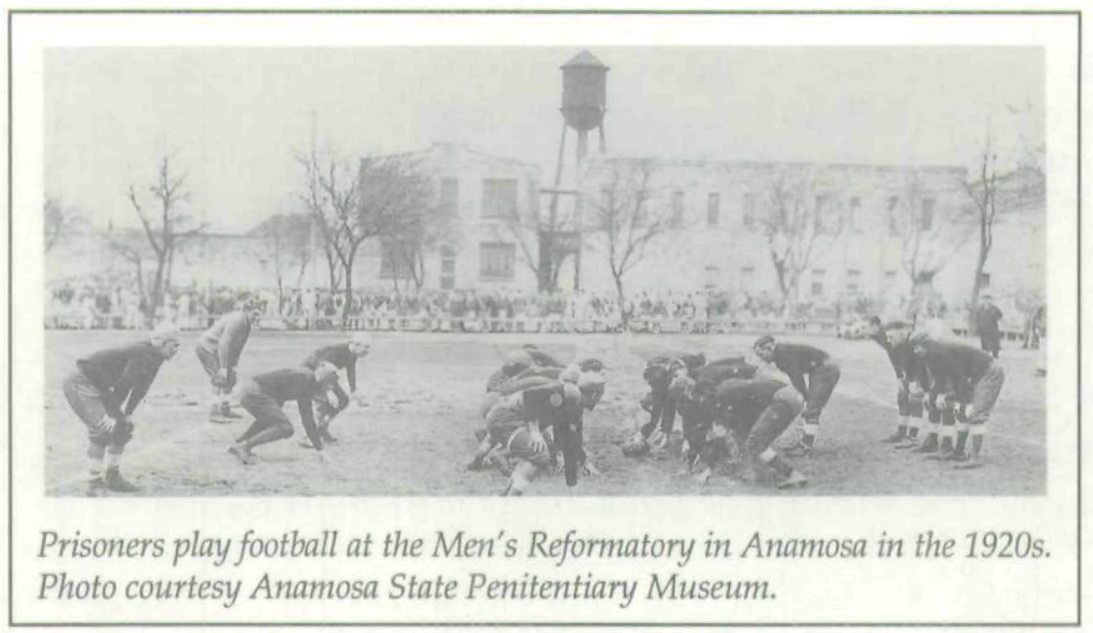

Still, corresponding to the general observation that it took at least a generation for reforms to be introduced into the program, the prisons did not develop a regularly scheduled recreation program integrated with its regular activities until the 1930s. During that decade, yard privileges became a daily routine rather than a luxury. By 1936, the Reformatory had instituted a seven-hour work schedule to allow daily exercise in the yard in the late afternoon and extended recreation periods on the weekends. A wide variety of team sports played a growing role in the prisons' programs. The State Penitentiary even hired a full-time athletic director in 1938, and inmates elected committees at both institutions to manage sporting events and other recreation. The expanded athletic programs allowed more prisoners to participate than when there was simply a select baseball team to represent the prison. Sports also uplifted morale and health and required group interaction and the development of responsibility. ${ }^{51}$

Religion continued to play an important role in efforts to reform prisoners in the Progressive Era. The chaplain continued

51. Board of Control, Report, 1936, 92, 103; ibid., 1938, 150, 164; ibid., 1940, 160; ibid., 1942, 136; Haynes, Iowa Prison System, 52; Haynes, "Glenn C. Haynes," 310-15, 331; Osborne Association, Handbook, 24-27, 43-45, 164; "History of the Iowa Board of Control"; Presidio, December 1966; Bess Sherman, interview, Anamosa, October 1990, copy of interview at Men's Reformatory, Anamosa. 


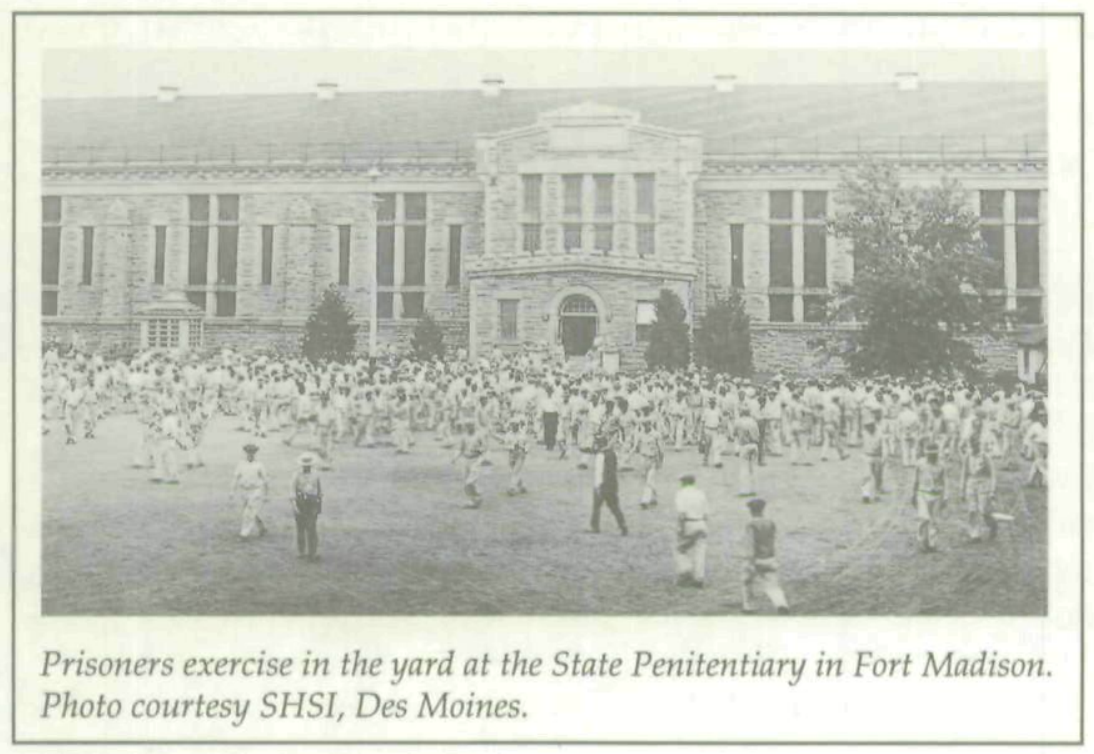

to play multiple roles, even serving as the athletic director at Fort Madison in the mid-1930s. The basic program changed little over the years, but it did become less exclusive and more individualized. At both institutions, religious services were held in the dining hall until the Reformatory dedicated a chapel in the center building in 1897 and the State Penitentiary completed a chapel in a wing of the industries building in 1932. After 1934, participation was no longer mandatory at Fort Madison, and leadership extended to include a part-time Catholic chaplain in addition to the full-time Protestant chaplain. The Reformatory experimented with an unsuccessful Christian Endeavor program from 1900 to 1904. At Fort Madison the chaplain held meetings at which inmates were encouraged to express and discuss their own views. ${ }^{52}$

The elaborate set of strict rules that governed prisoners' every move and applied equally to every prisoner under the Auburn system relaxed only very slowly. Even in 1905, the Iowa

52. Board of Control, Report, 1884, 24; ibid., 1900, 889-90, 921-23, 993-1000; ibid., 1902, 725-30; ibid., 1904, 987-90, 1053-57; ibid., 1936, 92; ibid., 1938, 14950; Osborne Association, Handbook, 21, 24-28, 43; Presidio, December 1966; Haynes, "Glenn C. Haynes," 312. 
State Penitentiary was still publishing 105 rules intended to maintain order. They governed actions from fighting to grimacing, cleanliness, visitation, and contraband. Most of these rules also applied at the Men's Reformatory, where a form of military discipline followed the model of the Elmira Reformatory. The intricacy of the prisons' system of rules did not allow effective enforcement and encouraged capricious discipline. Prisoner protests at the State Penitentiary in 1911, while not deteriorating into riots as they did in other state penitentiaries at about that time, did reflect the system's failure to achieve a balance between the need to maintain order and the relaxing of rules to fit the emerging reforms. The inspection of 1911 and the resulting Cosson Report noted the evils of solitary confinement and the silence system, but made few recommendations to reform the system generally. ${ }^{53}$

Two elements of the progressive reform program-the graded system, adopted in 1900, coupled with indeterminate sentencing (1907) - probably had the most marked effect on prisoners' lives. Each prisoner began in the middle of three grades and rose or fell according to his degree of obedience to the prisons' intricate system of rules. The inmate rose to the higher grade by earning a specific number of positive marks in the areas of conduct, work, and attitude. As he rose, he gained more privileges relating to attire, location in the dining hall, mail communication, use of the yard, and availability of reading matter and tobacco. Thus, the prisoner gained limited control over his treatment. Indeterminate sentencing and parole enhanced the grade system by providing a clear incentive for good behavior. After the parole board was established in 1907, it generally granted release to prisoners who had occupied the first grade for a specified period. ${ }^{54}$

53. Curtis, Five Years at Anamosa; McKelvey, American Prisons, 252, 290-95; Rothman, Conscience and Convenience, 148-57; American Correctional Association, American Prison, 148; Cosson, Report.

54. Board of Control, Report, ibid., 1900, 153, 928, 965; ibid., 1901, 65-66; B. G. Rees, former guard at the State Penitentiary and the Men's Reformatory, interview, 1957, transcript in archives of the Men's Reformatory, Anamosa; Osborne Association, Handbook, 35-37; Foss Davis, "A Classification Program for the Iowa Men's Reformatory," pamphlet, ca. 1948, Men's Reformatory, Anamosa. 
Over the course of the first four decades of the twentieth century, the State Penitentiary and the Men's Reformatory gradually addressed the goals of the progressive prison reform movement: individual classification and treatment, educational and vocational programs to meet the diverse needs of the inmates, the closer approximation of a normal community, and rapid return of prisoners to the community under supervision through the parole program.

At the State Penitentiary, counseling programs began in the 1940s. Although still limited by the amount of data available on inmate life histories and the small number of professionals, a screening committee studied prisoners' needs and recommended treatment. Medical facilities remained in inadequate quarters. Vocational programs began by 1940, when prison labor became less dominant as a means of financial support for the institution. The chaplain continued to serve multiple roles, including encouraging social interaction among prisoners. The prison newspaper, Presidio, also facilitated prisoner communication. Individually organized cell study programs helped to meet many inmates' educational needs. The prison allowed limited participation in the decision-making process through a sports program, other recreational opportunities, team participation, the publication of the Presidio, and the creation of a canteen. These activities promoted social interaction and the handling of responsibilities the activities entailed. Once prisoners were released, however, only limited volunteer and professional assistance was available to help them find and maintain employment and form relationships in their communities. ${ }^{55}$

The Men's Reformatory embodied many of the same improvements and limitations. An external study in 1938 noted that the physical plant was more conducive to ensuring safe custody than to facilitating rehabilitation; negative rather than positive rules governed discipline; the industries program continued to emphasize institutional support over vocational training; and the staff, quarters, and materials available for education

55. For insights about the experience of a "lifer" at the State Penitentiary in Fort Madison in the 1930s-1950s and about the impact of the Presidio and its longtime editor, see James McGrath Morris, "Leaves from a Lifer's Notebook: The Tom Runyon Story," Iowa Heritage Illustrated 78 (1997), 26-40. 
were insufficient for the needs of a reformatory. The reformatory also lacked case studies, diagnosis, classification, and treatment plans prepared by a properly trained staff. In light of these conditions, the study concluded that the Reformatory was "a wellmanaged junior prison rather than a true reformatory."

Progressive reforms did, however, begin to bear fruit in the early decades of the twentieth century. The state gradually improved physical conditions in the prisons; added more specialized staff, more educational opportunities, very limited vocational training, and more privileges allowing social interaction; gradually reduced the number of petty rules; placed less emphasis on prison labor; provided limited counseling while in prison and after release; developed better medical facilities; and removed short-term prisoners from within the prison walls. Despite the eventual acceptance of the progressive reform program, however, the prisons lacked the personnel and money to put the carefully balanced program fully in place. ${ }^{57}$

Iowa's state prisons, thus, failed to live up to reformers' expectations. Financial obstacles meant that reforms were slow to be enacted and haphazard. Even when the reform program reached its zenith between 1900 and 1910, the prisons failed to completely integrate the reform program into their activities. Instead, a small number of program segments became haphazard add-ons to the existing custodial prison routine. The programs did not noticeably improve the prisons' ability to reform and train their inmates. The formidable prison walls and row upon row of cells-some of which remained stacked upon one another-were a persistent symbol of the old Auburn system. Yet for all its failures, the reform movement had turned penologists and legislators from the objective of prisoner punishment to reform. ${ }^{58}$

56. Osborne Association, Handbook, 31; Haynes, Iowa Prison System, 46; Davis, "Classification Program for the Iowa Men's Reformatory."

57. McKelvey, American Prisons, 12, 234-38, 263-64; Rothman, Conscience and Convenience, 2; American Correctional Association, American Prison, 126-30, 134-35, 151, 156-57; Empey, American Delinquency, 374-76.

58. McKelvey, American Prisons, 112, 138, 157-60, 176-80, 184-89; American Correctional Association, American Prison, 80-87; John Bartlaw Martin, Break Down the Walls (London, 1955), 115; De Ford, Stone Walls, 54-55, 87. 


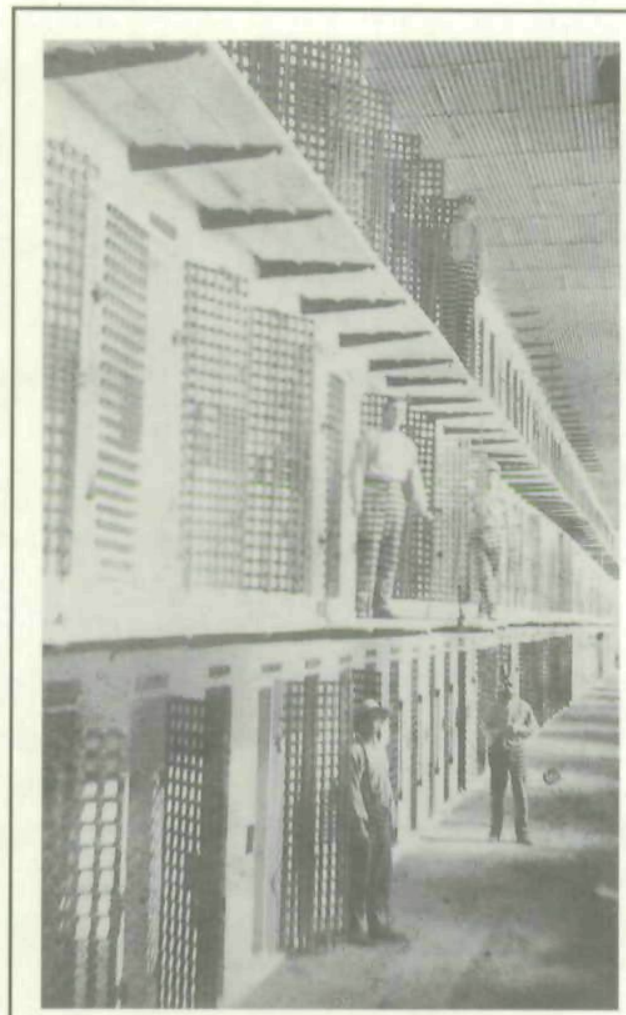

Stacked tiers of cells (ca. 1890) were a remaining reminder of the Auburn system of prison architecture and discipline. Photo courtesy SHSI, IC.

FAITH in the ability of progressive prisons to reform their inmates began to dim in the 1940s, but the movement had established the state's responsibility to rehabilitate its prison population. In the 1820 s and 1830 s, the 1870 s, and just after the turn of the century, reformers proposed programs to deal more effectively with social deviants. Iowa's legislators and prison administrators, like those in most other states, not only significantly delayed the implementation of such reforms, but almost always adapted only piecemeal reforms to existing programs. The result did not fully express the reformers' goals and failed to adequately reform either the prisons or their prisoners. 
Copyright of Annals of Iowa is the property of State of Iowa, by \& through the State Historical Society of Iowa and its content may not be copied or emailed to multiple sites or posted to a listserv without the copyright holder's express written permission. However, users may print, download, or email articles for individual use. 